\title{
Theatre for Sustainable Development: Jana Sanskriti's Participatory Ideologue and Practice
}

\author{
Teatr na rzecz zrównoważonego rozwoju: \\ Jana Sanskriti partycypacyjna ideologia i praktyka
}

\author{
Shubhra Ghoshal, Nirban Manna
}

\author{
Department of Humanities and Social Sciences \\ Indian Institute of Technology (Indian School of Mines), Dhanbad \\ Jharkhand, 826004, India \\ E-mail: ghoshal_shubhra@rediffmail.com \\ nirbanm@gmail.com
}

\begin{abstract}
As a reaction against the institutionalized top-down developmental orientation, the theory and praxis of development as an inclusive process of socio-political collective transformation has been constantly realized. At this juncture, performative activities have become increasingly instrumental strategies in engaging people more intrinsically in their various personal and social development issues. The focus of this paper lies in studying Jana Sanskriti Centre for Theatre of the Oppressed, which despite being an apolitical organisation, offers significant contribution towards searching for viable socio-political possibilities in contemporary India. The paper delves into discussing some specific ground realities of rural West Bengal, deliberating on the endeavours of Jana Sanskriti in extending onstage representations to offstage reformation. This research investigates how sustainable changes, defined as both individual psychological transformation and groups' socio-political consciousness are generated among spectators through participation in this theatrical process.
\end{abstract}

Key words: Theatre of the Oppressed, West Bengal (India), Sanjoy Ganguly, development, activism

\section{Streszczenie}

W reakcji na zinstytucjonalizowaną odgórną orientację rozwojową stale realizowano teorię i praktykę rozwoju jako integracyjnego procesu społeczno-politycznej transformacji zbiorowej. W tym momencie działania performatywne stały się coraz bardziej instrumentalną strategią angażowania ludzi bardziej wewnętrznie w różne kwestie rozwoju osobistego i społecznego. Artykuł ten koncentruje się na badaniu Centrum Teatru Uciśnionych Jana Sanskriti, które pomimo tego, że jest organizacją apolityczną, wnosi znaczący wkład w poszukiwanie realnych możliwości społeczno-politycznych we współczesnych Indiach. Artykuł zagłębia się w dyskusję na temat konkretnych realiów wiejskich Bengalu Zachodniego, rozważając starania Jana Sanskriti o rozszerzenie sztuki scenicznej na konkretne działania podejmowane poza nią. Zbadano, w jaki sposób trwałe zmiany, zdefiniowane zarówno jako indywidualna transformacja psychologiczna, jak i świadomość społeczno-polityczna grup, są wywoływane wśród widzów poprzez udział w tym procesie teatralnym.

Słowa kluczowe: Teatr Uciśnionych, Bengal Zachodni (Indie), Sanjoy Ganguly, rozwój, aktywizm

Introduction: Questioning development in Jana Sanskrit plays:

Jana Sanskriti's plays can be seen as socio-political critiques of institutionalised and biased development. For instance, the $2^{\text {nd }}$ scene of the play Gayer
Panchali (Song of the Village) evaluates the governmental poverty alleviation schemes. It focuses on IRDP scheme (Integrated Rural Developmental Programme), which is primarily intended for development of the rural mass, but the political corruption 
associated with their implementation deprives the deserving people of the developmental benefits:

Listen, the poor farmer holds onto the politician

And gets an IRDP loan

And the very next day,

That money feeds goes straight to the moneylender.

That's the kind of promise

(Ganguly, 2009, p. 26-7).

The next scene (scene 3 ) shifts to provide a glimpse of the local government body meetings. Their failure in handling the developmental projects is explored, which are subjected to corrupt leaders, political party demands, and the capitalistic political culture.

Panchayat Head: If we distribute all the loan money to the poor farmers based on the beneficiary list then our organization will die. If you ask why, then I would say... First Member [party supporter]: Yes, I think what the Head says is absolutely correct! Those of us in the organization we are primarily middle and big peasants. The government has said that the IRDP loans should go to poor agricultural workers. So in that case, we are ignored as if we are the scum that floats off the tidal wave

(Ganguly, 2009, p. 31).

Another play Amra Jekhaane Daariye (Where We Stand) presents the plight of industrial workers, identified as outcome of corrupt business alliances with trade union leadership (p. 14). In scene 1 of this play, when Maganlal (a factory owner) is being questioned for murdering Bikas (a factory worker), he defends himself as,

Maganlal: Oh go on mister! What problem? When a comrade goes against you, becomes a dissenting voice against you in the party, then what do you do? Tell me. Don't you remove him from this world? ... So I removed him ... You tell me, where is the injustice in this?

(Ganguly, 2009, p. 131).

In the consecutive scenes, this stifling of the rational voices towards questioning developmental issues is highlighted, along with accentuating the dearth of conscience in capitalists, policemen and the politicians, who fed on despotic political representation, misusing political, religious and communitarian ideologies. The last scene of the play shows the political leaders cultivating their vote banks, befooling the people with false promises, and engaging in violence or selfish collaboration with the opposing parties. The concerns of the mass are stated as:

First person: We want to live.

Second person: We don't have healthcare.

Third person: We don't have food.

Fourth person: Without treatment death calls us.
Fifth person: We have the ability to work, but there is no work.

Sixth person: They think we are puppets to play with.

Seventh person: They lie and cheat us.

Chorus: They make fools of us. Yes, they make fools of us

(Ganguly, 2009, p. 146-47)

Though the mass is judicious enough to discern the self-motivated politicians' treachery, their helplessness gets accentuated by corrupt political leadership in all the levels of representation. These excerpts reveal that the developmental projects devised for the dispossessed are, on the contrary, benefitting the decentralised power-holders, thereby, enabling structural closures of development for the larger section of the population.

\section{Theatre and sustainable development}

This scenario of West Bengal can be viewed as mirroring the larger panorama of the whole world in addressing the developmental issues. The concept of development comes into vogue after the Second World War which resulted in creating the first and third world binaries. The idea was to introduce mechanised developmental policies by the developed countries to the developing countries with the proclaimed objective of helping to raise the standards of living (Nogueira, 2002). However, though these Western attempts have benefitted the global economy, they have failed miserably in providing any sustainable model of development for raising the quality of living for two-thirds of the world population. The meaning and strategies towards development, are thus put under scrutiny, with the more recent approaches focussing on people's involvement in decision-making about issues impacting their lives by addressing specific needs and priorities relevant to people and empowering communities towards development (Prasad, 2009). At this juncture, art and cultural practices have become increasingly instrumental strategies in furthering community-based developmental models. By dint of its immediate convincing effects, performative art forms, especially theatre, has emerged as a feasible tool to engage people more intrinsically in their various personal and social development issues.

This gives rise to radical performative activities by theatre practitioners, directors and advocates, coming under the umbrella term Applied Theatre. It searches for a performative methodology aimed at changing the socio-political lives of certain communities. Theatre in the hands of the applied theatre practitioners becomes more a political and psychological liberation rather than represented action which would place the spectator no longer in an alienated and underdeveloped situation (Carlson, 1968), as mentioned in the applied theatre manifesto, Avignon Manifesto in 1968. 
This concept finds a new dimension of empiricality with Armand Gatti's involving audience to question the single ending of a play, and John O'Toole's vision of theatre as a process that would foster solidarity, dialogue and learning possibility among actors as well as the audience. This orientation sees its full bloom in Augusto Boal's application of Freirean dialogue as the practice of freedom in theatre. Following Brecht's and Freire's approaches of conscious engagement, Boal's objective behind developing the modus operandi of his Theatre of the Oppressed (TO) is to create a space for free dialogic interaction of ideas between the actors and the audience (Ghoshal and Manna, 2017). This theatre begins with enacting a scene where the protagonist faces some oppressive situation relevant to the particular audience. Then Joker, a figure acting as a neutral facilitator, invites the audience to suggest through enactment, ways to overcome the oppression. The same scene is played a number of times, exploring possible solutions to deal with the oppression. Boal thus believes in discussing the problems with the people who have first-hand experience of the problems, and thus strives to find new ways to explore participatory developmental theory. Later when Boal gets elected as the city councillor of the city Rio de Janeiro (Brazil), he merges his social responsibilities with theatre, democratizing policy-making by bringing people's opinion in formulating law through Legislative Theatre. Theatre of the Oppressed thus emerges as a development practice that uses performance as a participatory tool to help individuals and groups to share their experiences with the intent of social transformation. The impact and pertinence of this theatre has drawn attention from people throughout the world, and has been adapted and applied in their contemporary contexts by many groups.

\section{Developmental theatre in the Indian context:}

In India, the last couple of decades have witnessed a considerable rise of Social Action Groups (SAGs). Their use of theatre as a means of engaging people towards sustainable developments cater to both individual psychological issues (as depression, identity crisis, loneliness, self-esteem), as well as collective socio-political concerns (as creating support systems, re-evaluation of roles, positions and responsibilities in community and the system). The common techniques used by the SAGs include Playback theatre, theatre for the Disabled and Interactive Theatre. The technique of Theatre of the Oppressed is also one of the popular tools employed by the SAGs, as it not only re-tells the stories of the target group, but invites them to enact their suggestions. Thus the spectators no longer remain mere observers, but they are allowed to exercise their ability to think and imagine rationally about the problems, and experiment with different perspectives of problems, the spectators thus turning to what Boal calls spect-actors (speculating the problem as well as acting against it). In India, there are a handful of theatre groups, trying to explore notions of development through employing Theatre of the Oppressed (TO) techniques. This paper focuses on studying Jana Sanskriti, with which, theatre becomes more of a cultural and political praxis of a rehearsal for revolution. This paper first analyzes the methodology of Jana Sanskriti's work, and then discusses its approach and applicability towards developing strategies for achieving an integrated process of development towards betterment. The paper then delves into discussing how this theatre form questions the socio-political development not with a stark oppositional stance, but by attempting to develop a logical and objective view of perceiving the concept of development, and the developmental issues.

\section{Jana Sanskriti: An empirical approach towards sustainable development}

Jana Sanskriti is conceptualized by Sanjoy Ganguly, operating in West Bengal since 1985. Ganguly's experiences in trade union politics during his job as a factory middle-manager, makes him realize the problems of the slum-based working class, which they believe to be originating from the rural poverty and backwardness (Costa, 2007). Ganguly starts travelling and exploring rural lives and issues, where he observes the multiple oppressive factors reigning in the villages, such as poverty, lack of basic health and educational infrastructures, political hooliganism and gender inequality. Ganguly's altruistic intention finds a form of expression with his realization of the potential of theatre and folk art forms as the most convincing and immediate means of reaching the mass. Thus, Jana Sanskriti (JS) is inaugurated with a group of theatre artists, scripting plays on representing problems and suggesting their ideal solutions through folk theatre forms. However, Ganguly realizes that the rural people are more acquainted with their own problems, and are more potent in sustaining themselves in spite of facing insurmountable oppressions in their daily lives, whereas the outsiders can feel the issues merely at the surface level. And thus, the Jana Sanskriti plays remain idealistic representations, rather than realistic presentations, failing in realizing the impact it expects. The exigency is not to educate or aware the mass, but to provide access to information, to create a platform to voice and discuss their issues, and to acknowledge their existence and contribution. In search of a participatory forum, Jana Sanskriti finds a definite and more appropriate way of functioning after Ganguly comes in contact with Boal's and Paulo Freire's ideas in the 1990s. He realizes the discriminatory power relations between an altruist (actor) and a re- 
cipient (spectator). As Augusto Boal felt monologic oppression in Brazilian politics and Freire finds it in the banking education system, Sanjoy Ganguly also identifies the contemporary socio-political and cultural scenario as strictly monopolized by political leaders and culturally dominant mainstream artists. Inspired by Boal's principles, his games, exercises and techniques, Ganguly establishes Jana Sanskriti as the centre for Theatre of the Oppressed, which ventures to give shape to a dialogic theatre, mingling a depoliticised notion of development and active social work. Since then, this organisation has evolved with the aim of helping local communities learn how to use theatre as a language for critical self-reflection, exploration, and analysis in order to articulate new direction that can lead to both individual and communal transformation (Mills, 2009).

Jana Sanskriti has its main training and administrative centre at Badu, Madhyamgram in South 24 Paraganas and its operation zones include North and South 24 Paraganas, Murshidabad and Midnapur districts of West Bengal. At present, there are more than thirty satellite theatre teams operating in West Bengal. The core JS group works in collaboration with other theatre groups and NGOs, and visits many countries abroad holding performances and workshops. Due to its effective methodology and popularity, JS has now established its extension links in Bihar, Jharkhand, Madhya Pradesh, Uttar Pradesh, Gujarat, Maharashtra, Tripura and New Delhi. Jana Sanskriti's modus operandi consists of three integral practices: workshops, performances, and activism.

\section{a. Workshops}

The workshops are generally held in an open-air mango grove at Badu, Jana Sanskriti's main centre. JS also organises TO workshops in collaboration with other theatre groups, NGOs and SAGs in other cities throughout the country and abroad also. The workshops aim at learning, practicing, and developing the process of Theatre of the Oppressed, which involves training the physical, cognitive, rational, ideological and aesthetic faculties of the participants. Workshop sessions begin with simple warm-up exercises, which develop cognitive coordination, sense of space aesthetics, and expressiveness of the physique. These are followed by gamesercises (as Boal terms, synthesizing games and exercises), which, along with relieving the trenuosity of exercises on one hand, also help in raising consciousness, and building the sense of collectivity on the other. Another significant technique employed by this methodology is Image theatre, which is believed to be more expressive, as bodily images are better embodiments of spontaneous inner emotions. Here, real images of oppression are countered by the possible ideal images, thereby discovering subtle strategies of fighting real life oppressions towards desirable alternatives. These static images are consecutively developed into a series of moving images, which initiates the making of a forum. Characters and dialogues are invented and evolved by the participants themselves, thus constructing ensemble forums to be performed before the spectators.

\section{b. Performances}

Performance in Jana Sanskriti does not confirm to the conventional structure of playing scripts, but instead, conceives it as a process of scripting plays. To realize and internalize the rural oppression, Jana Sanskriti group itself stays in the target villages. It interacts with the local experienced people and also the authoritarian bodies operating there, so as to locate the root cause and accountability of the problems. The scripts are then composed, consisting of a few oppressive situations, voicing experiences of the immediate victims. The performance generally begins with chorus song or kaathi naach (a type of dance performed with sticks), which sets the mood of the play at the beginning. However, the situations are kept unresolved and open to be discussed by the actors and the audience during the forums, which follows the enactment of the entire play once. In the forum sessions, the debatable situations are re-enacted consecutively, with the intension of intervention from the audience. The spectators are expected to stop the questionable scenes, step into the performance space, and act-out the role of one of the characters in an alternate way, which s/he assumes to be a solution to solve or deal with the issue. In case of no voluntary intervention on the audience's part, Joker (a facilitator playing an integral role in the functioning of JS Forums), needs to create such a congenial atmosphere so as to ensure maximum participation and an uninhibited forum on the part of the spectators. The alternative actions of fighting oppression acted out by the spect-actors, are countered by the actors with oppressive ideologies, with the intension of developing an engaging, in-depth and dynamic perception of oppression and thereby, to discover pragmatic ways of countering it. Thus, the workshops and performances help in training the bodies to express and fight oppression, in developing the logistics of analysing the issues, and in building the courage to carry out activist actions against real life oppressions. When a forum is repeated a number of times to the same spectators, they gradually develop a better understanding of the issues, better strategies of fighting them, and also, greater resolution and fortitude to face them.

Participatory forum plays, in general, are often assumed to be unable of dealing with complex issues. The reason being given is that as the forums address mass audience with the objective of encouraging participation, the plays bear the risks of getting reduced to well-defined simple representations, providing little scope for the critical objectivity of the spectators to use. However, Jana Sanskriti's plays are political representations embedded in the multiple histories of power and representations, and 
not at the service of any particular ideology. The characters are not flat empathetic beings, but are complex metaphoric embodiments of politics, culture and power. Many characters individually, can be seen as possessing the aspects of both the oppressed and the oppressor. As an instance, in one of the depiction of political corruption in the local government body meetings (excerpt mentioned above), the scene reveals the helplessness of some of the representatives, who are bound to submit to the unethical higher authoritative party demands, in spite of being power holders in the eyes of the oppressed. At these points, the plays pause, without providing any climax or resolution, so as to instigate the critical reasoning faculties of the spectators to probe the issue. The objective of Jana Sanskriti is to change and ameliorate the power equations, by allowing a democratic space, binding no one to any specific oppression. The open-endedness of Jana Sanskriti plays not only creates critical spect-actors, but also provides the means to re-script reality in their own terms, bringing the methods of representation to the extent that they are fundamentally in sync as modes of constructing political struggle (Ganguly, 2009). In the last excerpt, it is quite evident that in spite of being fully conscious and informed of the treachery of the parties, the mass have no other alternative. In the same play, the last scene depicts four different parties, having more or less the same agendas, trying to lure the people with false expectations and promises, whereas the exhausted people run helplessly from one party to another in utter confusion. However, Jana Sanskriti believes in availability of multiple alternatives, which needs to be discovered. When this scene is performed in a forum, this moment freezes as an image, open to be re-enacted by the spect-actors in search of possibilities. In one intervention, the spect-actor tries to persuade the others in not paying heed to their words, pointing out their selfish motives. But when another actor asks, but what is the alternative? (pointing to the four leaders) Either it is him, or it is the other or it is the third ... We have to choose from amongst them, then the spect-actor falls short of any counter-argument, and retreats. The forum continues with suggestions of forming a new party, of making the people aware, of initiating an armed struggle, and of following non-cooperation with the leaders. However, the most significant intervention is enacted by Prabhati, who stands in the middle of the people and waves her waistband like a flag, implying a call to throw over the domination of the corrupt political leaders and set up an independent people's organization (Ganguly, 2010). Thus the forums provide the means of imagining alternatives to situations, and rehearsing the courage to experiment on them to assess their pragmatics.

\section{c. Activism}

Jana Sanskriti's ultimate objective does not end with a rehearsal for revolution, but it strengthens with
JS's solidarity in taking the same risks in the process of bringing about the revolution. Ganguly believes in developing spectactivism and disallow spectatorship or spectacularity (Yarrow, 2017), thereby extending spect-acting on the stage towards spect-activism in reality off the stage. It signifies a much more involved grassroot activism, having individualistic and collective, as well as direct and contingent impact. The core JS team as well as the JS satellite teams work collectively with activist orientation towards social development. Besides conducting protests, processions and rallies, Jana Sanskriti holds discussion forums addressing region specific issues, engaging right from the first-hand oppressed, to the covertly impacted ones to the authoritative bodies, exchanging information and experiences, thereby collectively creating and contributing to the knowledge tank as well as the think tank. Jana Sanskriti comes up with follow-up programmes after the forums, holding meetings to discuss the specific action points, the specific authoritative bodies to be approached, and the specific actions that need to be undertaken. Interested active volunteers are also specified during the process, and included as members in a people's committee initiated by JS, known as Human Rights Protection Committee, acting at the grassroots level, providing a common identity to villagers who raise their voices against oppression, fight against exploitation, and uphold their rights to education, health, shelter, etc., through grassroots activism (Dutta, 2015). Campaigns emphasizing girl child education, demanding better health facilities, protesting against illegal liquor consumption and corrupt ration system, have been carried out through these spect-activists.

Illegal liquor production, sale and consumption have become a major issue in the rural areas. Besides conducting forums on alcoholism, generating awareness and discussion space, Jana Sanskriti has helped in creating a mass disapproval of alcohol shops, demanding their closure. However, the alcohol producers and owners got the support of some corrupt politicians and policemen, and also, having criminal orientations, their position remains secured. At this point, Jana Sanskriti steps and joins the movement in creating a collective of four hundred people, blocking roads, insisting on seizure of illegal alcohol production houses, which ultimately is acknowledged and abided by the local police and authority.

Another program initiated by Jana Sanskriti is the Theatre in Education project, with its emphasis on experimenting with the approaches towards teaching and learning through theatre aesthetics. This educational initiative known as VSEC (Vivekananda Support Education Centres), sets off in 2013, with the primary objective of experiencing the joy of learning. This innovative strategy of Jana Sanskriti, of teaching the primary syllabus of the government schools through theatrical aesthetics have helped in mainstreaming more than five hundred slow learn- 
ers. Jana Sanskriti believes in involving the students' families also, especially the mothers, where forums on child health and development, parenting, education, psychology, familial as well as social issues are conducted. This promising impact has resulted in drawing the attention of the government schools, and attempts of imbibing JS methodologies in the regular primary and secondary curriculum are also being considered.

However, as repercussion of these endeavours, Jana Sanskriti team has to encounter threat, violence and opposition in carrying out their activities. Jana Sanskriti has to confront a number of off-stage menaces, as its activism has angered various sections of local government officials, factory and land owners, and politicians. Sanjoy Ganguly, along with the JS members have been threatened a number of times, with attempts of murder, forcing them to take respite as refugees to other cities to sustain themselves. Also, other than political, there are various social and financial hindrances encountered by the Jana Sanskriti activists. Orthodoxical views against women working in theatre, and even this form of theatre itself, (without stage, light and music) (Costa, 2010) have created obstacles in Jana Sanskriti's smooth functioning and have also demotivated the members at times. However, continuous genuine efforts of Jana Sanskriti in creating a dialogic space regarding the people's need, in building cordial relationships with the localites, in taking the same risks (Boal, 2006), and in imbibing the democratic approach in its whole process of working, have developed a durable solidarity of the Jana Sanskriti team with the common people.

Thus, though Jana Sanskriti is an apolitical activist group, over time, it has succeeded in earning trust and reliability with not only the local mass, but also with the local government heads. The members work actively in close collaboration with the Gram, Panchayat and Block Development Officials, so as to ensure effective implementation of the developmental schemes. As an instance, the intervention of Jana Sanskriti in Mid-Day Meal (MDM) scheme is worth mentioning. When West Bengal State Government's MDM scheme of providing free meals to school students is initiated, the two dominant local political parties start fighting over attaining its control, so that the allotted fund can be procured, misappropriated and misused by the parties for their selfish ends. As a result of these political motives, the execution of this scheme comes to a halt in a number of schools. In Kulpi, the most active area of Jana Sanskriti's working, the BDO seeks for Jana Sanskriti's intervention to mediate over the issue. Jana Sanskriti teams discuss the case with the local people, local committees, and local government officials, and suggest the formation of local Mata Shiksha Samitis (Mothers' Committees) for running this scheme. To ensure quality performance and democratic participation, the committee members are suggested to be selected from current students of the respective schools, which also need to be changed each successive year. The successful functioning of this new strategy thereafter is a considerable step of liberating the development policies from selfish political clutches, and handing over the ownership to responsible local leadership.

\section{Conclusion: Towards sustainable development}

Thus, Jana Sanskriti is an apolitical organization, which aims at stimulating and developing political consciousness among people to mobilize social action. The existing political culture tends to hegemonize power among limited authorities, by building separations between reality and representation, the oppressed and the powerful, politics and culture, the expert and the unaware, and the artist and the spectator (Dutta, 2010). These unequal representations are addressed and transgressed by Jana Sanskriti's practice of cultural aesthetics. Jana Sanskriti's practice democratizes the process of viewing power relations and representational politics. The on-stage representations might be ephemeral, but are bound to produce a sustained impact in the long run, through continuous performances. Thus, Jana Sanskriti believes in long term engagements with the place and the people. Not only do they perform the same play to the same spectators at least thrice, but also build up solidarity in taking the same risks as spect-activists. Most of the activist theatres fail in the aesthetic aspects of theatre, thus attenuating the efficacy of artistic expression and communication. Jana Sanskriti amalgamates folk art forms with various Western and Image theatre techniques, fusing realistic and metaphoric elements to present subtle representations of social and political power relations. Jana Sanskriti's theatre provides a safe space to observe, think, imagine and practice multiple alternatives, and consequently, to construct better realities. The inspiring spect-actorship of Prabhati in Where We Stand points out another aspect of developmental possibility. It is observed that Prabhati, in spite of being an agricultural worker who is preoccupied the whole day with household chores, holds a significant position at home, because she gets and avails the opportunity of having a say in every decision making in her household. This brings about another realization in Jana Sanskriti, that true empowerment begins at the family level, only then it can be expected to be executed at a higher level. During forum interventions, the actors' and the spect-actors' logical encounters prove to be fertile grounds of introspecting and rationalizing own actions. The actors, spect-actors and the spectators develop the objectivity and realization to recognize the oppressed and the oppressive aspects of their own selves, as well as their own potentials, individuality and latent possibilities. The process develops introspection within the people, giving rise to logical and humanitarian beings, 
capable of taking appropriate decisions, as well as actions. This internal revolution gets reciprocated in the attempt of an external revolution through the actions of the spect-activists. Thus, it can be said that the decision making power and representational politics needs to be decentralized not only to the state levels but also to the family, and the individual level, so as to experience a sustainably developed equitable society.

\section{References}

1. BOAL A., 2006, The Aesthetics of the Oppressed, trans. Adrian Jackson, Routledge, London and New York.

2. CARSON M. A., 1984, Theories of the Theatre: A Historical and Critical Survey, from the Greeks to the Present, Cornell University Press, Ithaca and London.

3. COSTA D.D. (ed.), 2010, Scripting Power: Jana Sanskriti on and Offstage, CAMP, Kolkata.

4. COSTA D.D., 2007, Tensions of neo-liberal development: State discourse and dramatic oppositions in West Bengal, in: Contributions to Indian Sociology, 41(3), p. 293
5. DUTTA M., 2015, Theatre for Social Change, Diss. Tata Institute of Social Sciences, p. 61-69.

6. GANGULY S., 2009, Where WE Stand: Five Plays from the repertoire of Jana Sanskriti. Trans. Dia Mohan Dacosta, CAMP, Kolkata.

7. GANGULY S., 2010, Jana Sanskriti: Forum Theatre and democracy in India, Routledge, New York.

8. GHOSHAL S., NIRBAN M., 2017, Boal's Reception in India: Dialogism of Jana Sanskriti's Theatre of the Oppressed, in: Journal of Dharma, 42(1), p. 201218.

9. MILLS S., 2009, Theatre for transformation and empowerment: a case study of Jana Sanskriti Theatre of the Oppressed, in: Development in Practice, 19(4-5), p. 551.

10. NOGUEIRA M.P., 2002, Theatre for Development: An Overview, Research in Drama Education, in: The Journal of Applied Theatre and Performance, VII(1), p. 3.

11. PRASAD K., 2009, Communication for Development: Reinventing Theory and Action, BR Publishing Corporation, New Delhi.

12. YARROW R.. 2017, From performers to spectactivists: Jana Sanskriti's training for agency in and beyond theatre, in: Indian Theatre Journal, 1(1), p. 2937. 
